\section{LA REFORMA ELECTORAL DE 1912 Y LA IMPUGNACIÓN ANARQUISTA}

JUAN SURIANO

Juan Suriano es Profesor del Instituto de Altos Estudios Sociales de la Universidad Nacional de San Martín.

e-mail: lobatosuriano@websail.com.ar

\section{Resumen}

En esta comunicación se abordará una de las aristas de la reforma electoral implementada a partir de 1912 vinculada al impacto que ésta generó entre aquellas organizaciones que pretendían representar a los trabajadores nativos como socialistas, sindicalistas o anarquistas. Particularmente se analizará el impacto sobre las estrategias políticas del anarquismo, sin duda una de las tendencias con mayor influencia entre los trabajadores argentinos de comienzos del siglo y único agrupamiento político que impugnó abierta y frontalmente los cambios en el sistema comicial.

\section{Summary}

This communication focuses on one of the awn of electoral reform implemented in 1912 relating to the impact it generated among those organizations claiming to represent native workers as socialists, trade unionists and anarchists. In particular it will analyze the impact on the political strategies of anarchism, without doubt one of the most influential trends among Argentine workers of the beginning of XX century, and single political grouping that direct and frontally challenged the electoral system changes. 